\title{
INVESTIGATING SELF-COOLING EFFECTS OF VENTILATED ATTICS UNDER DIFFERENT ROOF AND AMBIENT TEMPERATURES IN SUMMER
}

\author{
Zhigang SHEN, Shimin WANG \\ Durham School of Architectural Engineering and Construction, University of Nebraska-Lincoln, \\ 68588-0500 NE, USA \\ Received 17 Jul 2012; accepted 12 Sep 2012
}

\begin{abstract}
An unsteady computational fluid dynamics model is employed to simulate summer-time buoyancy-driven turbulent ventilation in gable-roof attics of residential buildings. The energy performance of vented attics is assessed by comparing their performance to sealed attics with the same geometry and insulation configurations. The simulated boundary conditions of the roof-top temperature ranging between $295.15 \mathrm{~K}$ and $345.15 \mathrm{~K}$, coupled with an ambient temperature ranging between $295.15 \mathrm{~K}$ and $315.15 \mathrm{~K}$, resemble the summer attic conditions with effects of solar irradiance on the roofs. Simulation results indicate that both the vented and sealed attics are dominated by thermal stratification. The cooling load of the sealed attic is predicted to be about 3 times greater than that of the vented attic for a roof-top temperature of $345.15 \mathrm{~K}$ and an ambient temperature of $305.15 \mathrm{~K}$. Both the cooling load and ventilating air flow rate of the vented attic are sensitive to the ambient temperature variation.
\end{abstract}

Keywords: attic, summer, natural ventilation, cooling load, turbulence, CFD.

\section{Introduction}

Building performance simulation is important for understanding the operational characteristics of built environment and has broad impacts on real world applications (Laouadi 2009; Sartipi et al. 2010; Cropper et al. 2010; Blocken et al. 2011; Al-Khameis et al. 2011; Goldsworthy 2012; Saber et al. 2012). In the United States, residential buildings consume $35 \%$ of the total electricity, and around $10 \%$ of the energy consumption is used in air conditioning (D\&R International 2012). Attics have been identified as an important contributor to the cooling load of residential buildings in summer time. As such, many approaches have been taken to reduce the heat flux from the attic in summer time. Natural ventilation in attics has been identified and utilized as one effective and low-cost solution for reducing residential summer cooling load in different climate areas (Rose, TenWolde 2002; Hutchings 1998; Rudd, Lstiburek 1998). Despite the wide acceptance of attic natural ventilation in residential construction, the technical data used to quantify ventilation requirements in building codes are very limited. Numerical simulation (Chen 2009; Chen, Srebric 2002; Chow 2008; Jurelionis, Isevičius 2008) of naturally ventilated attics provides an effective approach to supply such technical data for developing low-energy residential buildings (Parasonis et al. 2012; Džiugaitė-Tuménienè et al. 2012).

The majority of the previous research on air flow and heat transfer in attic spaces is concerned with natural convection in sealed triangular enclosures, as reviewed by Kamiyo et al. (2010) and by Saha and Khan (2011). Although the air flow in real residential attics is almost always turbulent, the majority experimental and numerical studies (e.g. Flack, Witt 1979; Flack 1980; Poulikakos, Bejan 1983; Holtzman et al. 2000; Asan, Namli 2000; Ridouane et al. 2005; Lei et al. 2008; Kent 2009; Saha et al. 2010; Saha 2011) in this area devoted to the analysis of flow and heat transfer under laminar conditions, and only a few studies (e.g. Ridouane et al. 2006; Talabi et al. 2006) investigated turbulent flow and heat transfer in sealed attics.

Previous studies involving attic ventilation are quite limited in the literature. For example, Medina et al. (1998a, b) proposed a correlation-based mathematical model for vented residential attics and compared model predictions with experimental data, and Moujaes and Alsaiegh (2000) employed a finite element model to simulate the thermal effects of placing a radiant barrier system inside a vented residential attic for a case study under summer weather conditions. As one part of attic research series, we recently reported our findings on buoyancydriven attic ventilation in winter time under turbulence conditions (Wang et al. 2012).

In this paper, the energy performance of unconditioned residential attics under summer conditions is investigated to quantitatively assess the benefit of passive attic ventilation in cooling load savings under various roof and ambient temperatures, which resemble the summer attic conditions with effects of solar irradiance on the roofs. The authors are aware there are cases, in which attics are air-conditioned in some regions. Air-conditioned attics 
are not in the scope of the investigation. The research context and summer temperature boundary conditions can be found from Figure 1 (Rudd, Lstiburek 1998). One of the important aspects of the paper is to understand solar chimney effects of the naturally ventilated attics on its energy performance, namely, hot roof enhanced natural ventilations.

We expect that the results from this study will provide some insights about the how solar irradiance may facilitate the natural ventilation in the attics, and lead to reduced cooling load compared to unventilated attics. The buoyancy-driven air flow and natural convection heat transfer under summer conditions are modelled by using ANSYS Fluent 13.0 (ANSYS Inc. 2011). The $k-k l-\omega$ transitional model (Walters, Cokljat 2008), which is a physics-based transitional turbulence model capable of modelling turbulent flows from laminar-turbulence transitional regime to fully turbulence regime, is adopted to simulate a wide range of the roof-top and ambient temperatures. As an eddy-viscosity turbulence model based on the $k-\omega$ framework, the $k-k l-\omega$ model includes laminar kinetic energy to represent the pretransitional fluctuations in boundary layers. Unsteady Reynolds-averaged NavierStokes (URANS) modelling is used for solving the targeted natural convection problems. The URANS has been shown to be an effective approach to overcome numerical stiffness and improve solution convergence in previous studies for natural convection flows in enclosures (Ozoe et al. 1985; Henkes et al. 1991; Henkes, Hoodendoorn 1994; Hsieh, Lien 2004).

\section{Numerical model}

A schematic diagram of a cross-section plan of the physical model of the vented attic is shown in Figure 1. In the direction perpendicular to the cross-section shown in Figure 2, it is assumed that the building is long enough to ignore the effects of the gable-end walls, and thus the problem is simplified to two dimensional. The modelled attic space is in a shape of an isosceles triangle, with a ceiling width of $2 \mathrm{~W}$ and a height of $H$, resulting in a pitch of $H / W$. Due to the buoyancy stableness of the summertime attic ventilation as well as the assumed symmetry in both geometry and boundary conditions, only the right half of attic is included in the computational domain. It should be noted that the 2D and symmetric assumptions adopted in this study refer to the time-averaged mean velocity and temperature distributions, which are actually solved by the CFD software; as for the total turbulent quantities with fluctuation components included, the flow and temperature fields are by nature $3 \mathrm{D}$ and asymmetric.

In this study, the modelled attic is assumed to have a fixed ceiling half-width of $W=4 \mathrm{~m}$ and a roof pitch of $5 / 12$, corresponding to a pitch angle of $22.62^{\circ}$. For simplicity, neither roof nor ceiling trusses are included in the model, and the computational domain is only occupied by air, which is assumed to be a Boussinesq fluid with a reference temperature $T_{0}$ specified to the outside ambient air temperature to correctly calculate the buoyancy effects. In this study, the ambient temperature is assumed to vary between $295.15 \mathrm{~K}$ and $315.15 \mathrm{~K}$.

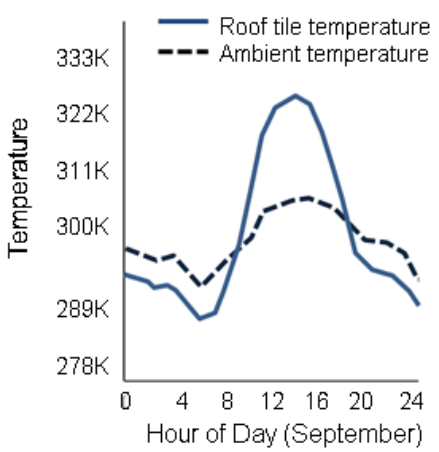

Fig. 1. Typical hot summer roof tile temperature compared to ambient temperature (Rudd, Lstiburek 1998)

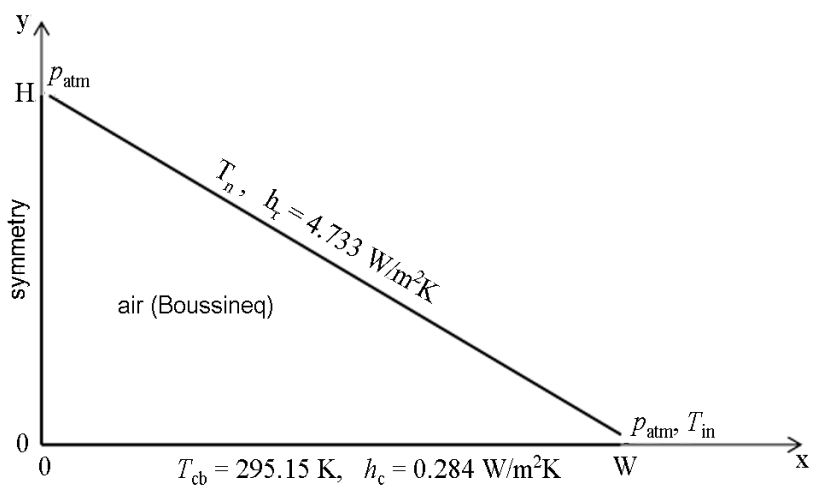

Fig. 2. Schematic of the computational domain and boundary condition

In order to correctly account for the thermal resistances of the ceiling and roof, which are excluded from the computational domain, convection-type boundary conditions are applied to both the ceiling and roof boundaries. For example, energy balance across the ceiling thickness gives:

$$
\left.\lambda \frac{\partial T}{\partial y}\right|_{y=0}=\frac{\lambda_{\mathrm{c}}}{t_{\mathrm{c}}}\left(\left.T\right|_{y=0}-T_{\mathrm{cb}}\right)=h_{\mathrm{c}}\left(T_{\mathrm{ct}}-T_{\mathrm{cb}}\right)
$$

where: $T_{\mathrm{cb}}$ and $T_{\mathrm{ct}}$ are the temperatures at the ceilingbottom and ceiling-top, respectively; and the heat transfer coefficient $h_{\mathrm{c}}$ is determined by the thermal conductivity of ceiling material $\lambda_{\mathrm{c}}$ divided by ceiling thickness $t_{\mathrm{c}}$.

In this study, a ceiling-bottom temperature is specified to $T_{\mathrm{cb}}=295.15 \mathrm{~K}$, while a heat transfer coefficient of $h_{\mathrm{c}}=0.284 \mathrm{~W} / \mathrm{m}^{2} \mathrm{~K}$ is adopted to approximate a ceiling insulation level of R-20. Similarly, a heat transfer coefficient of $h_{\mathrm{r}}=4.733 \mathrm{~W} / \mathrm{m}^{2} \mathrm{~K}$ (equivalent to an insulation level of R-1.2) is specified to the roof boundary to simulate a condition of a $3 \mathrm{~cm}$ plywood roof, and the roof-top temperature is allowed to vary between $295.15 \mathrm{~K}$ and $345.15 \mathrm{~K}$.

The buoyancy-driven cases considered in this paper are corresponding to worst-case scenario without winds, which generally enhance the attic ventilation. For all the simulations of the vented attic, pressures at the soffit and ridge vents are specified to be zero gauge pressure. Therefore, the obtained air flow is purely driven by the thermally induced buoyancy forces, i.e. the stack effect. At 
the soffit vent, the inlet air is assumed to enter at the ambient temperature with a turbulent intensity of $1 \%$. For the sealed attic, the geometric configuration and insulation conditions are kept the same as for the vented attic, except that the ridge and soffit vents are replaced by insulated walls.

Following the URANS approach to turbulence, the time-averaged air velocity $\left(u_{i}\right)$, pressure $(p)$, and temperature $(T)$ distributions in the attic space shown in Figure 1 are governed by the continuity, momentum, and energy equations (Wang et al. 2012), which are solved by ANSYS Fluent 13.0 (ANSYS Inc. 2011), with the space variables being discretized by the finite volume method and time domain discretized by the fully implicit scheme. The coupled algorithm is employed for solving the pressure and velocity coupling. The discretization of pressure is based on the second order scheme, while the third-order MUSCL scheme is adopted for all the other variables.

Non-uniform triangular grids are employed, and the boundaries are inflated with nodes tightly clustered near the walls to ensure that the $\mathrm{y}+$ value for the first grid close to the walls is everywhere less than 1 .

Since there is no comparable experimental attic data found in the literature, especially for vented attics, the present numerical model is validated through a benchmark problem of mixed turbulent convection in a square cavity, which has been studied both experimentally (Blay et al. 1992) and numerically (Blay et al. 1992; Zhang, Chen 2000; Zhang et al. 2007). The validation method has been used by many (Zuo, Chen 2009; Horikiri et al. 2011; Kuznik et al. 2007) and recommended by Chen and Srebric (2002). The mixed turbulent convective air flow within a $1.04 \times 1.04 \mathrm{~m}$ cavity is created by a horizontal plane wall jet entering from an inlet slot at the ceiling level together with a heated floor. Subject to the experimentally measured boundary conditions (Blay et al. 1992), the predictions of the present model are shown in Figures 3 and 4 . The predicted mean velocity pattern shown in Figure 3 is very similar to that measured from the experiment (Blay et al. 1992) and that averaged from large eddy simulation (Zhang, Chen 2000), while the predicted profiles of velocity and temperature agree well with the experimental data, as shown in Figure 4.

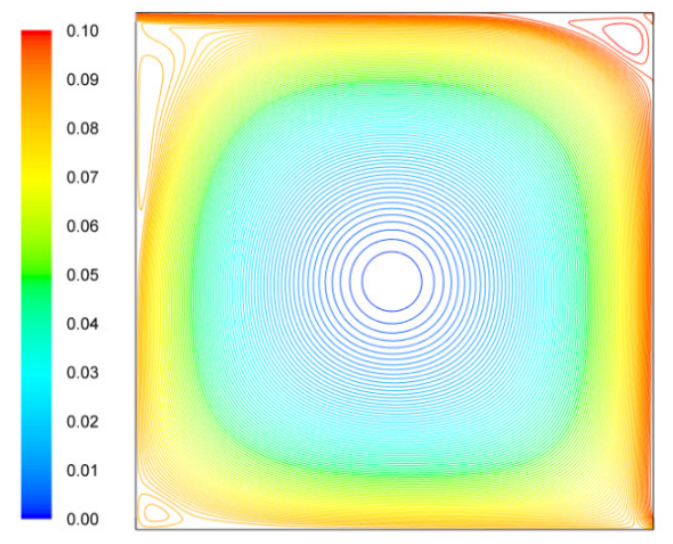

(a)
The modelling results presented in this paper are based on grids consisting of about 40,000 nodes and a time step size of $1 \mathrm{~s}$. All the calculations start from initial conditions of zero velocity and uniform temperature. Within each time step, 20 iterations are executed. Numerical experiment show that decreasing the time step to $0.5 \mathrm{~s}$ or requiring 40 iterations in each time step generate negligible difference in solutions. In addition, a grid dependence test shows that refinement of the grids by doubling the node numbers results in less than $2 \%$ difference in the total mass flow rate and wall heat transfer rate results.

\section{The parametric study}

The effects of roof and ambient temperatures are investigated for the vented and sealed attics, respectively. For all the cases investigated, the simulation converges to a steady solution after $\sim 3500$ time steps. For the sealed attic, air flow is confined inside the attic space, and there is no direct mass transfer between the ambient and the attic air. As a result, the cooling load of the sealed attic is expected to be independent of the ambient temperature. For the vented attic, however, both the ambient temperature and the roof-top temperature affect the cooling load and the ventilating air flow rate. In reality, both the ambient temperature and roof-top temperature change with time constantly and may have unlimited combinations. An economic way to investigate the effects of the ambient and roof temperatures is following a parametric approach by keep one temperature fixed and varying another and vice versa. This is the approach we adopted here.

\subsection{Effects of ambient temperature $\left(T_{i n}\right)$ for vented attic}

Figure 5 shows the predicted velocity and temperature distributions for the vented attic with a fixed roof-top temperature of $T_{\mathrm{rt}}=325.15 \mathrm{~K}$ and an ambient temperature varying between $295.15 \mathrm{~K}$ and $315.15 \mathrm{~K}$. It is clear that the general patterns of both the flow field and the temperature field are qualitatively independent of the ambient temperature variation. For all the ambient temperature cases, the outside air enters from the soffit vent, travels along the roof bottom for a distance of the roof length,

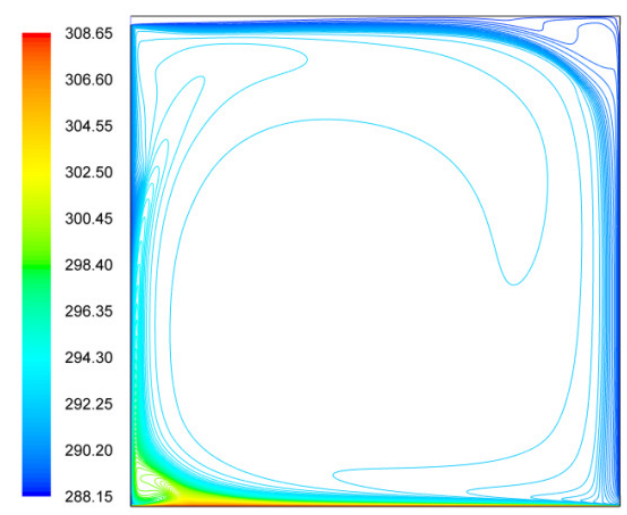

(b)

Fig. 3. Predicted (a) streamlines (in $\mathrm{kg} / \mathrm{m} \mathrm{s}$ ) and (b) isotherms (in K) for the validation case of turbulent mixed convection in a square cavity 


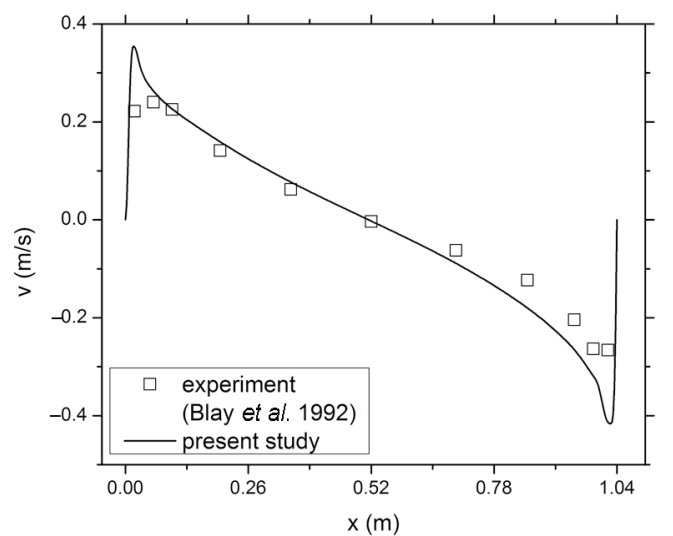

(a)

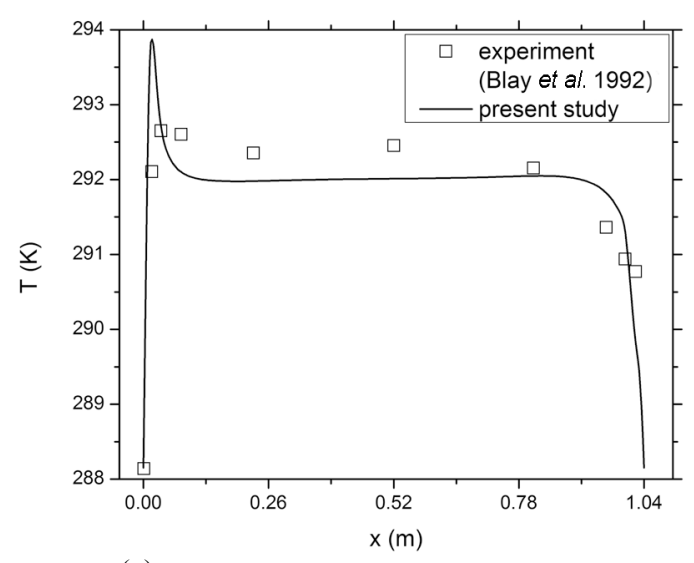

(c)

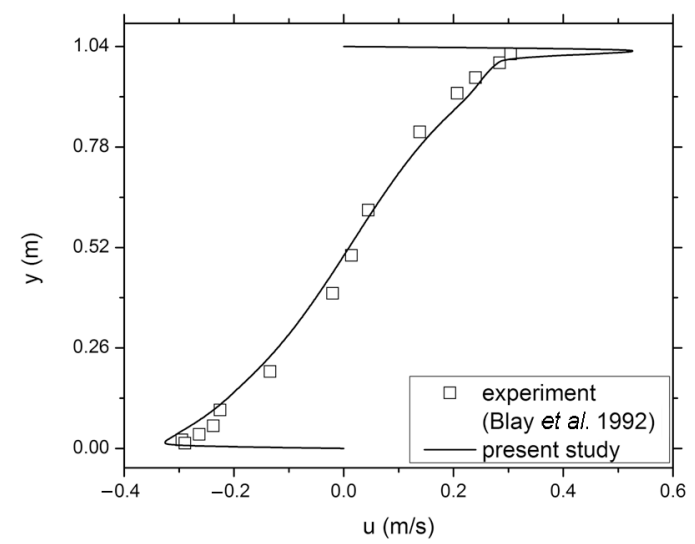

(b)

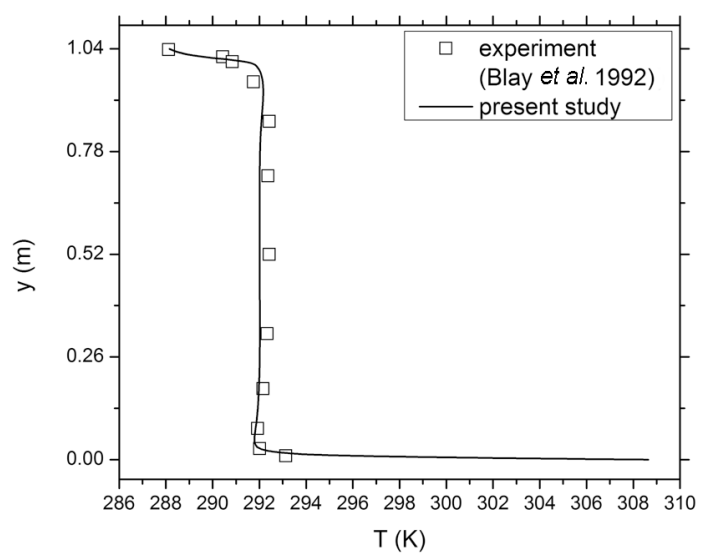

(d)

Fig. 4. Comparison of modeling predictions with experimental data for the validation case: (a) vertical velocity along the section of $y=0.502 \mathrm{~m}$; (b) horizontal velocity along the section of $\mathrm{x}=0.502 \mathrm{~m}$; (c) temperature along the section of $\mathrm{y}=0.502 \mathrm{~m}$; and (d) temperature along the section of $\mathrm{x}=0.502 \mathrm{~m}$

and then follows two different paths. The mainstream of the ventilating air continues traveling along the roof bottom and leaves the attic from the ridge vent, while a portion of the ventilating air travels a "detoured" zigzag path bounded by three convection cells: a counter clockwise swirling cell near the soffit, a clockwise one occupying more than half of the attic space, and another counter clockwise one under the top portion of the roof. The isotherms indicate that for all the ambient temperature cases, the thermal boundary layers develop along both the roof and ceiling boundaries, and the attic space is dominated by thermal stratification, except for the soffit region.

The dependence of the vortex intensity of the circulating cells as well as the minimum and maximum temperatures inside the attic space on the ambient temperature is depicted in Figure 4 as well. It is clear that an increase in ambient temperature leads to a decrease in both the total mass flow rate of the ventilating air and the vortex intensity. The reduction in mass flow rate is indicated by the decrease in the maximum value of the stream function and detoured portion of ventilating air flow, while that in vortex intensity is reflected by the reduced number of streamlines associated with the clockwise swirling convection cell. Such results can be explained by the decreasing temperature difference between the roof-top and the ambient, which is the drive force for the attic air flow. Figure 5 further shows that both the minimum and maximum temperatures inside the attic space increase with the ambient temperature, indicating that the cooling effect of the attic ventilation declines with the increasing ambient temperature.

The horizontal velocity profiles along the vertical line $\mathrm{x}=2 \mathrm{~m}$ for the vented attic with a fixed roof-top temperature of $325.15 \mathrm{~K}$ and various ambient temperatures are depicted in Figure 6a. For each ambient temperature case, the vertical line $\mathrm{x}=2 \mathrm{~m}$ cuts through two or three convection cells (Fig. 5), and the horizontal velocity shown in Figure 6a changes directions at corresponding heights accordingly. The velocity peak under the roof is associated with the mainstream ventilating air flow and decreases with the increasing ambient temperature, as a result of decreasing driving temperature difference.

The predicted temperature profiles along the symmetric line $\mathrm{x}=0$ for the vented attic with a fixed roof-top temperature of $325.15 \mathrm{~K}$ and various ambient temperatures are shown in Figure 5b. For all the ambient temperature cases, the temperature increases almost linearly with $\mathrm{y} / \mathrm{H}$, except in the regions near the ceiling and the ridge vent, where much greater temperature gradients indicate the effects of the ceiling and roof thermal boundary layers. It is also clear from Figure $5 b$ that both the average attic temperature and the temperature gradient decrease with the increase in the ambient temperature, due to the cooling effect decrease along with the increasing ambient temperature. 

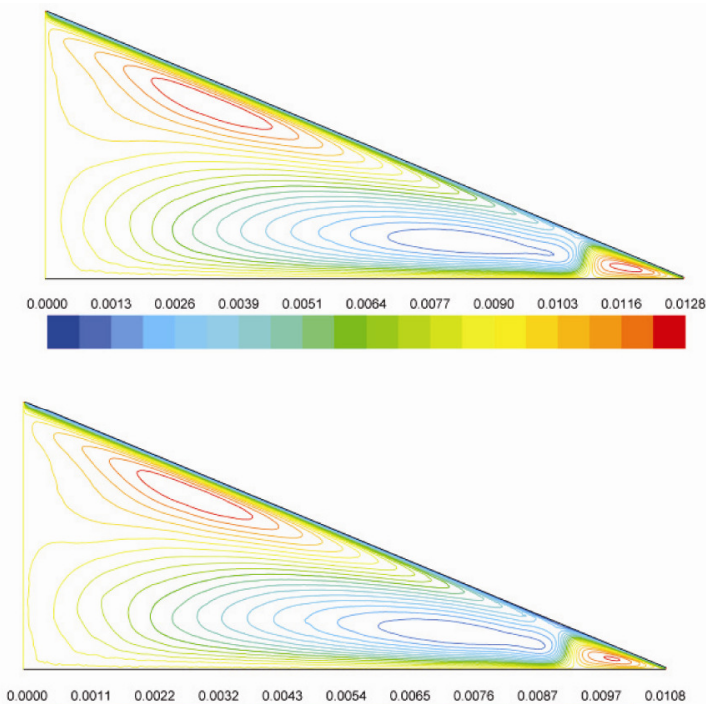

$\begin{array}{lllllllllll}0.0000 & 0.0011 & 0.0022 & 0.0032 & 0.0043 & 0.0054 & 0.0065 & 0.0076 & 0.0087 & 0.0097 & 0.0108\end{array}$

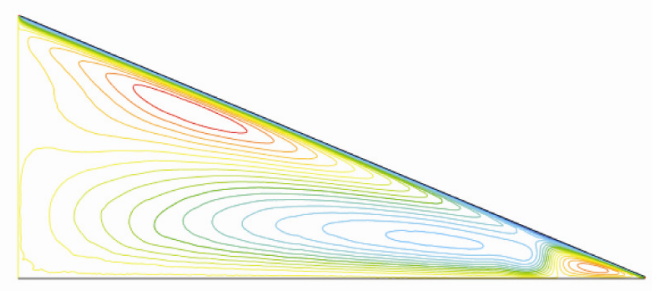

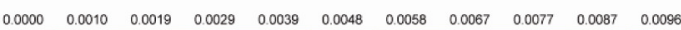
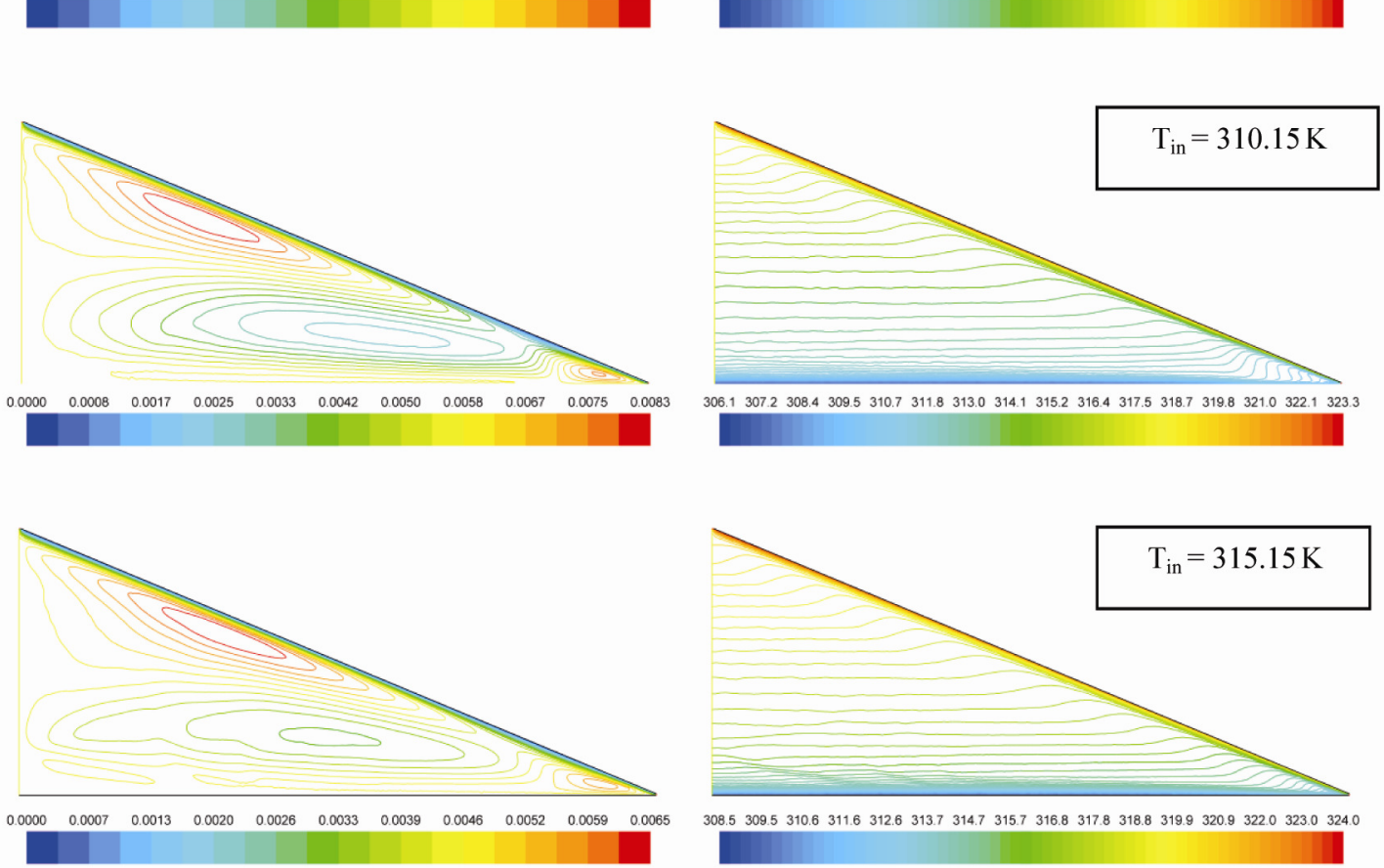

Fig. 5. Predicted (left) streamlines (in $\mathrm{kg} / \mathrm{m} \mathrm{s}$ ) and (right) isotherms (in K) for the vented attic with a fixed roof-top temperature of $325.15 \mathrm{~K}$ and various ambient temperatures.dd a descriptive label of the figure here
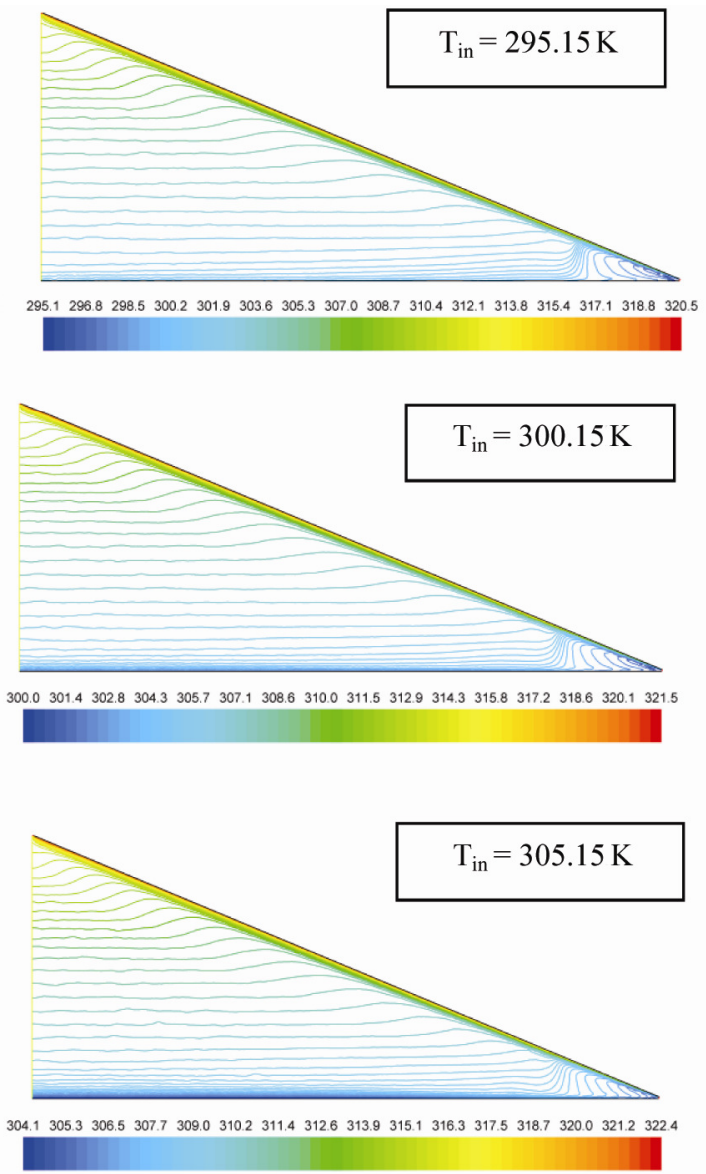


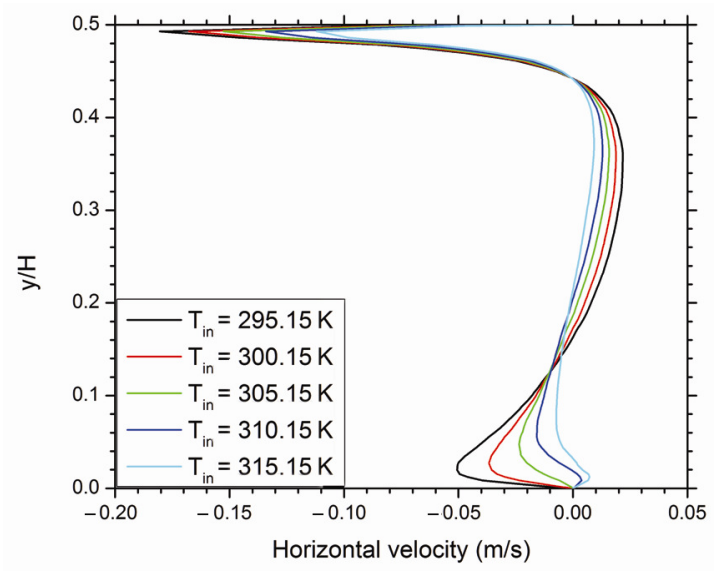

(a)

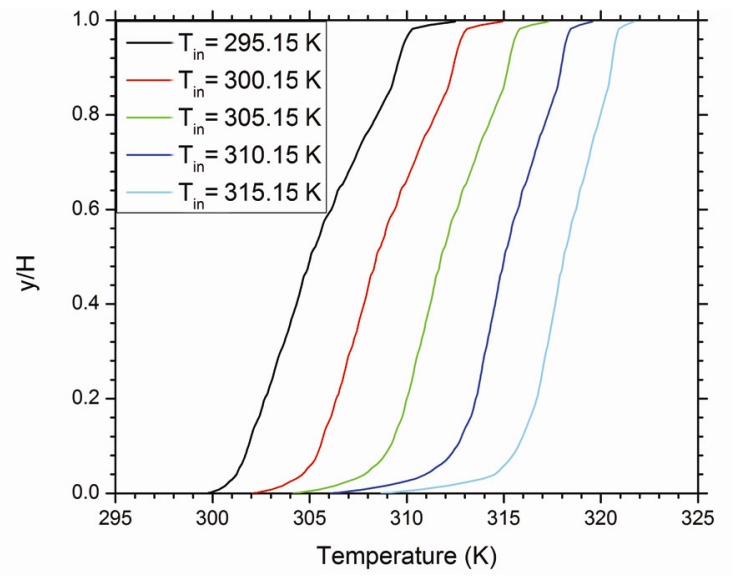

(b)

Fig. 6. Predicted profiles of (a) horizontal velocity at along the vertical line $\mathrm{x}=2 \mathrm{~m}$; and (b) temperature along the symmetric line $\mathrm{x}=0$ for the vented attic with a fixed roof-top temperature of $325.15 \mathrm{~K}$ and various ambient temperatures

\subsection{Effects of roof-top temperature (Trt) for vented attic}

The predicted velocity and temperature distributions for the vented attic with a fixed ambient temperature of $\mathrm{T}_{\mathrm{in}}=305.15 \mathrm{~K}$ and a roof-top temperature varying between $295.15 \mathrm{~K}$ and $345.15 \mathrm{~K}$ are shown in Figure 7. The results for the case with a roof-top temperature of $325.15 \mathrm{~K}$ are not shown in Figure 7, because they have been shown in Figure 5. The flow field and the temperature field for the cases with a roof top temperature higher than $315.15 \mathrm{~K}$ shown in Figure 7 share the same general patterns as those shown in Figure 5. However, the predicted air flows and temperature distributions for the cases specified with a roof-top temperature of $295.15 \mathrm{~K}$ and $305.15 \mathrm{~K}$ follow completely different patterns.

The fundamental reason for this difference is that when the roof-top temperature is lower or equal to the ambient temperature, the ventilating air flow is downward, i.e. entering from the ridge vent and leaving from the soffit vent, as a consequence of the fact that the ambient air is actually cooled inside the attic. As compared to the $295.15 \mathrm{~K}$ case, the $305.15 \mathrm{~K}$ case is associated with much slower air flow and much uniform temperature distribution, especially in the top portion of the attic space. For the cases with a roof-top temperature higher than the ambient temperature, the streamline distributions in Figure 7 show that the upward air flow rate and the vertex intensity of the convection cells increase with the roof-top temperature, in consistent with the increase in the total temperature difference across the attic space, as indicated by the isotherm distributions in the figure. The predicted horizontal velocity profiles along the vertical line $\mathrm{x}=2 \mathrm{~m}$ for the vented attic with a fixed ambient temperature of $305.15 \mathrm{~K}$ and various roof-top temperatures are shown in Figure 8a. The velocity profiles for the $295.15 \mathrm{~K}$ case and the $305.15 \mathrm{~K}$ case are dramatically different from the other cases. For the cases with a roof-top temperature higher than or equal to the ambient temperature, the velocity peak under the roof monotonically increases with the roof-top temperature. The predicted temperature profiles along the symmetric line $\mathrm{x}=0$ for the vented attic with a fixed ambient temperature are shown in Figure 8b. For all the roof-top temperature cases, the predicted temperature in the attic space increases with $y / H$, as a result of thermal stratification, and the average attic air temperature increases with the roof-top temperature. For the cases with a roof-top temperature higher than the ambient temperature, the vertical temperature gradient increases with the roof-top temperature as well.

\subsection{Effects of roof-top temperature (Trt) for sealed attic}

The modelling results of the sealed attic (with the rooftop temperature varying from $305.15 \mathrm{~K}$ to and $345.15 \mathrm{~K}$ ) are shown in Figures 9 and 10. The streamline distributions in Figure 9 exhibit a qualitatively similar pattern, dominated by two convection cells, regardless of the difference in roof-top temperature. Air flow in the top cell along the roof is counter clockwise and associated with a stronger vortex (as manifested by a greater number of streamlines in a narrower space), as compare to the underlying clockwise swirling cell along the ceiling. The streamlines above the ceiling boundary are not smooth, which is caused by many tiny convection cells formed along the ceiling. The predicted temperature fields for all the cases shown in Figure 9 are characterized by a combination of thermal boundary layers developed along the roof and ceiling boundaries and thermal stratification occupying most of the attic space. It is clear from Figure 8 that both the vertex intensity of the convection cells and the total temperature difference across the attic space increase with the roof-top temperature.

The horizontal velocity profile along $\mathrm{x}=2 \mathrm{~m}$ (Fig. 10a) indicates that the air flow in the roof boundary layer has a much higher peak velocity than that in the ceiling boundary layer. This is mainly caused by the roof slope, which allows the buoyancy forces to develop and drive the air flow, as compared to the horizontal ceiling, along which buoyancy forces cannot build horizontal gradient and the air flow is purely driven by pressure difference. The temperature profile along the symmetric line $\mathrm{x}=0$ (Fig. 10b) clearly shows the trend that both the average attic temperature and its vertical gradient increase with the roof-top temperature. 

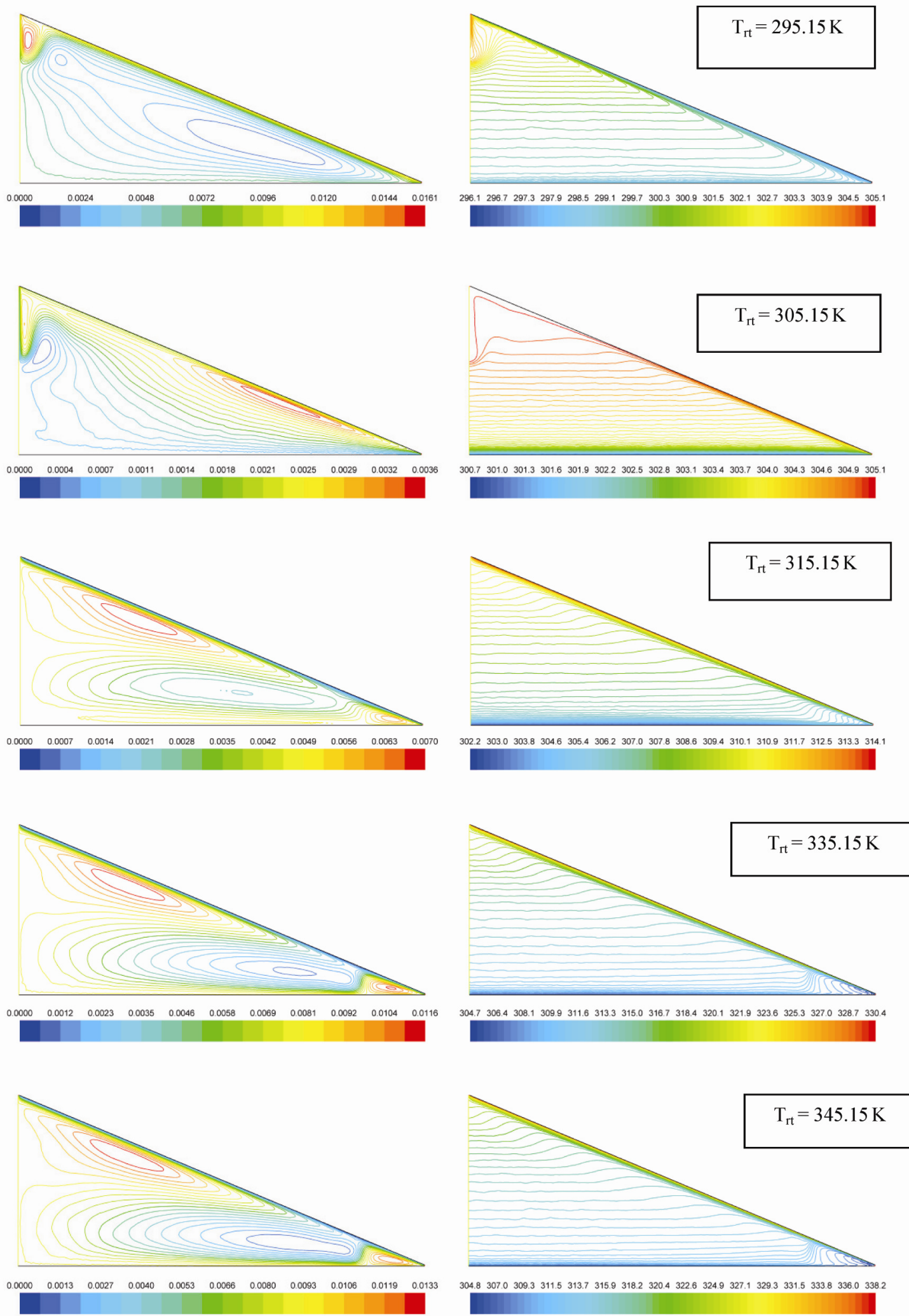

Fig. 7. Predicted (left) streamlines (in $\mathrm{kg} / \mathrm{m} \mathrm{s}$ ) and (right) isotherms (in K) for the vented attic with a fixed ambient temperature of $305.15 \mathrm{~K}$ and various roof-top temperatures 


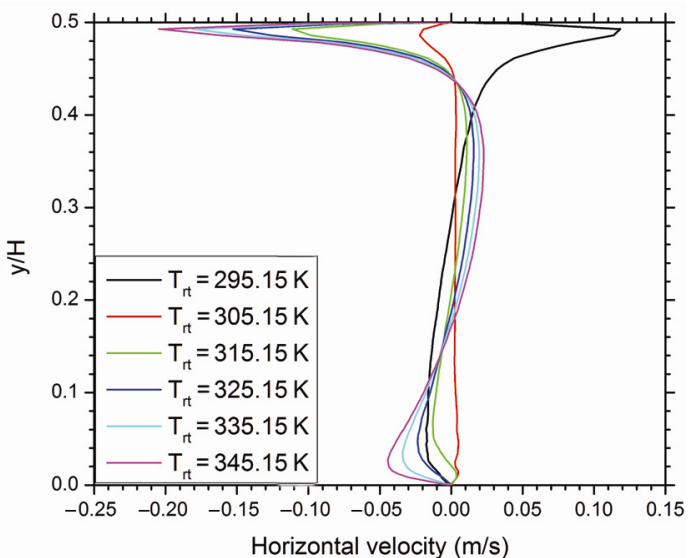

(a)

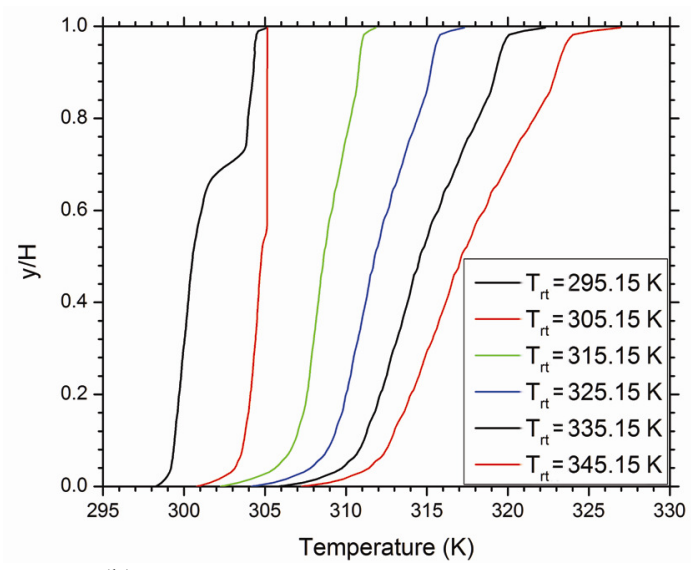

(b)

Fig. 8. Predicted profiles of (a) horizontal velocity at along the vertical line $\mathrm{x}=2 \mathrm{~m}$; and (b) temperature along the symmetric line $\mathrm{x}=0$ for the vented attic with a fixed ambient temperature of $305.15 \mathrm{~K}$ and various roof-top temperatures

\section{Summary of the parametric study}

The overall effects of the roof and ambient temperatures on the ventilating air flow rate and attic cooling load are presented in Figures 11-13. Figure 11 shows the predicted ventilating mass flow rate through the vented attic as a function of the roof-top temperature as well as the ambient temperature. For a given ambient temperature of $305.15 \mathrm{~K}$, increasing the roof-top temperature from $295.15 \mathrm{~K}$ to $305.15 \mathrm{~K}$ results in a decrease in downward mass flow rate from $\sim 0.005 \mathrm{~kg} / \mathrm{s} \mathrm{m}$ to $\sim 0.002 \mathrm{~kg} / \mathrm{s} \mathrm{m}$, while the upward air flow increases by $41 \%, 70 \%$, and $92 \%$, respectively, as the roof-top temperature increases from $315.15 \mathrm{~K}$ to $325.15 \mathrm{~K}, 335.15 \mathrm{~K}$, and $345.15 \mathrm{~K}$. On the other side, the ventilating air flow rate is predicted to decrease monotonically with the increase in the ambient temperature. For a fixed roof-top temperature of $325.15 \mathrm{~K}$, the ventilating mass flow rate decreases by $9 \%$, $19 \%, 31 \%$, and $48 \%$, respectively, as the ambient temperature increases from $295.15 \mathrm{~K}$ to $300.15 \mathrm{~K}, 305.15 \mathrm{~K}$, $310.15 \mathrm{~K}$, and $315.15 \mathrm{~K}$.

The predicted attic cooling load as a function of the roof and ambient temperatures for both the vented and sealed attics is shown in Figure 12. All the three curves in the Figure exhibit monotonic increase of the attic cooling load (measured by heat transfer through the ceiling boundary) along with the roof-top or ambient temperature. However, the increasing slopes for the three curves differ remarkably. The cooling load of the vented attic increases with the roof-top temperature at a much lower slope, as compared to the curve corresponding to the sealed attic. As a result, the sealed attic has a cooling load about 2 to 4 times greater than that of the vented attic, if the roof-top temperature is $345.15 \mathrm{~K}$, although the cooling loads of the sealed and vented attics are comparable at the rooftop temperature of $305.15 \mathrm{~K}$. This result clearly shows the advantage of attic ventilation in reducing the attic cooling load under typical summer conditions. Figure 12 also indicates that the cooling load of the vented attic increases by $269 \%$ as the ambient temperature increases from $295.15 \mathrm{~K}$ to $315.15 \mathrm{~K}$ while the roof-top temperatu- re is fixed at $325.15 \mathrm{~K}$. Such a result implies that the cooling load of vented attics is very sensitive to ambient temperature, and attic ventilation is most effective for reducing cooling load in climate zones with relatively low ambient temperature but very strong solar radiation.

The predicted heat gain from the roof as a function of the roof and ambient temperatures for the vented attic is presented in Figure 13. For sealed attic, the heat gain from the roof is not shown in Figure 11, because the overall energy balance of the attic requires the roof heat gain equal to the cooling load, which is shown in Figure 12 already. It is clear from Figure 13 that the roof heat gain increases monotonically with the roof-top temperature, but decreases monotonically with the increasing ambient temperature. Comparing Figures 12 and 13 indicates that the roof heat gain is an order of magnitude higher than the heat loss through the ceiling. Therefore, most of the heat entering the attic through the roof is carried out by the ventilating air flow. In other words, attic ventilation provides an effective mean to cool the roof using the ambient air.

\section{Conclusions}

In this study, a numerical model is employed to evaluate the summer-time energy performance in triangular attics with passive ventilation systems. The impacts of roof-top and ambient temperatures on the cooling load and ventilating air flow are investigated. The findings from the numerical results are summarized as follows.

The increase of roof temperature (due to solar irradiance) leads to increased natural ventilation rate in the ventilated attics, which significantly reduced the cooling load compared to the unventilated/sealed attics. This result provides scientific guidance to design energyefficient attics. For example, a design to further increase attic ventilation ratio may further reduce summer cooling load of attics.

For both the vented and sealed attics, the attic spaces are dominated by thermal stratification, and the cooling load is predicted to increase monotonically with 

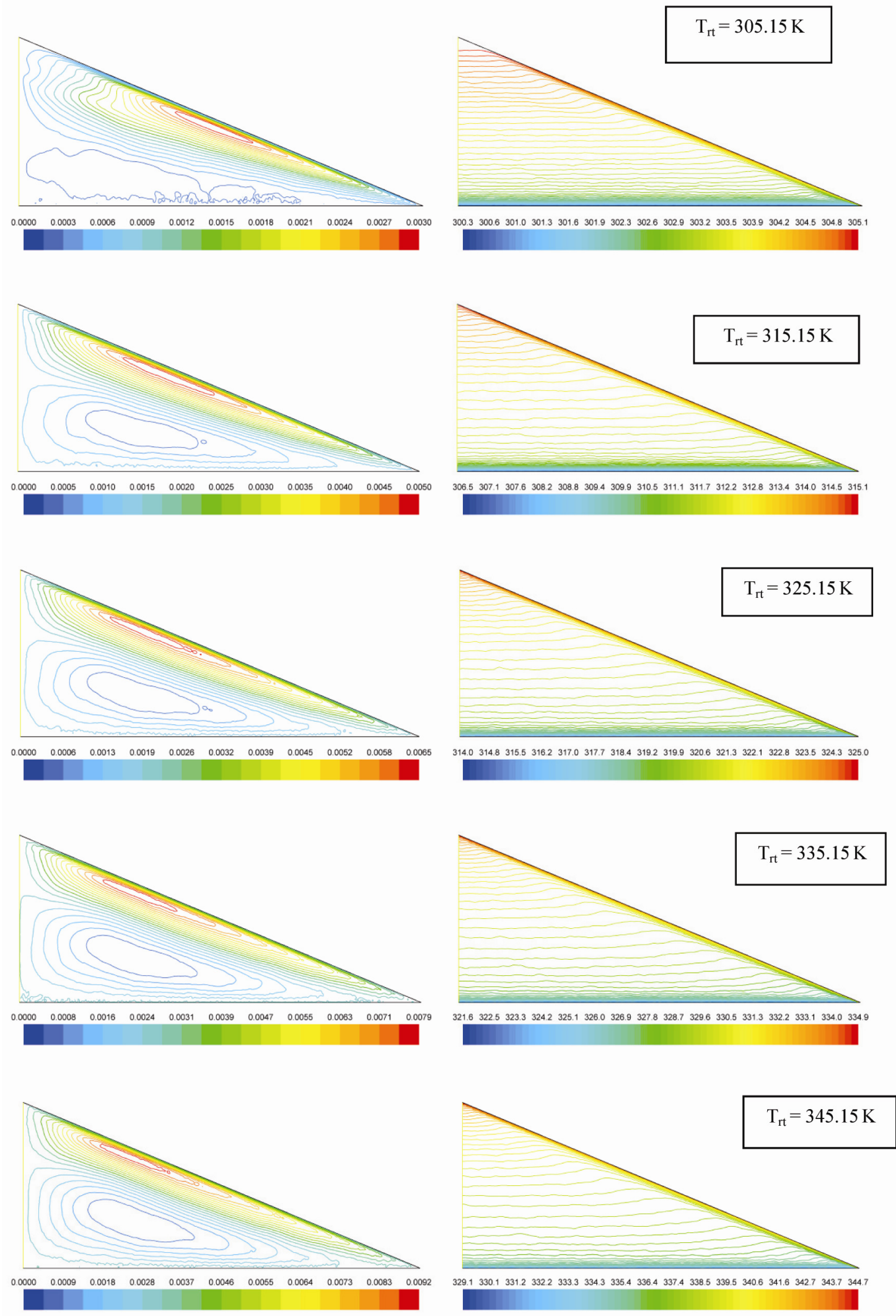

Fig. 9. Predicted (left) streamlines (in $\mathrm{kg} / \mathrm{m} \mathrm{s}$ ) and (right) isotherms (in $\mathrm{K}$ ) for the sealed attic with various roof-top temperatures 


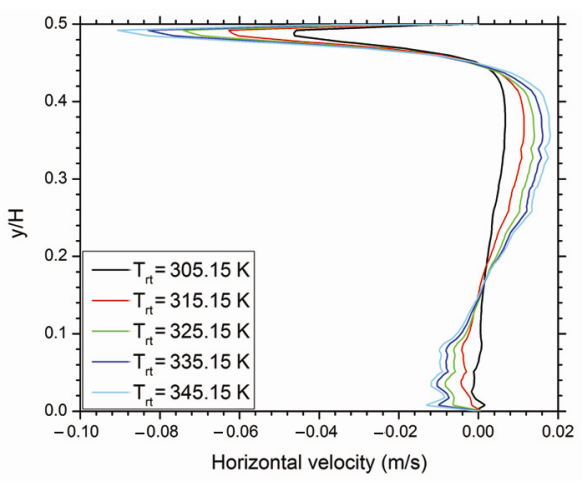

(a)

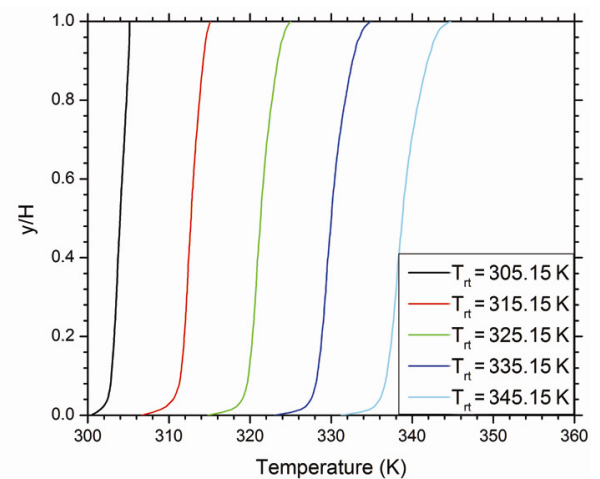

(b)

Fig. 10. Predicted profiles of (a) horizontal velocity at along the vertical line $x=2 \mathrm{~m}$; and

(b) temperature along the symmetric line $\mathrm{x}=0$ for the sealed attic with various roof-top temperatures

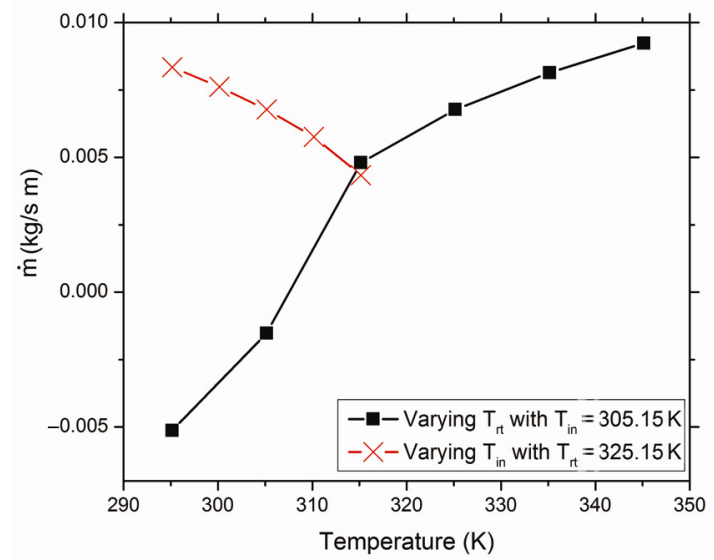

Fig. 11. Predicted ventilating mass flow rate as a function of the ambient and roof-top temperatures for the vented attic

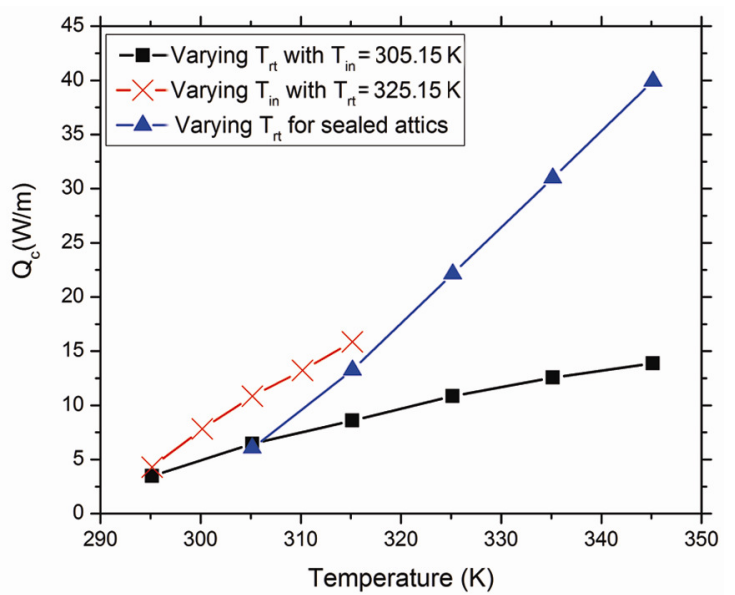

Fig. 12. Predicted attic cooling load as a function of the ambient and roof-top temperatures for the sealed and vented attics

the roof-top temperature. However, the cooling load of the sealed attic increases with the roof-top temperature at a much greater rate than the vented attic. For the case with a roof-top temperature of $345.15 \mathrm{~K}$ and an ambient temperature of $305.15 \mathrm{~K}$, the sealed attic has a cooling load about 3 times that of the of the vented attic

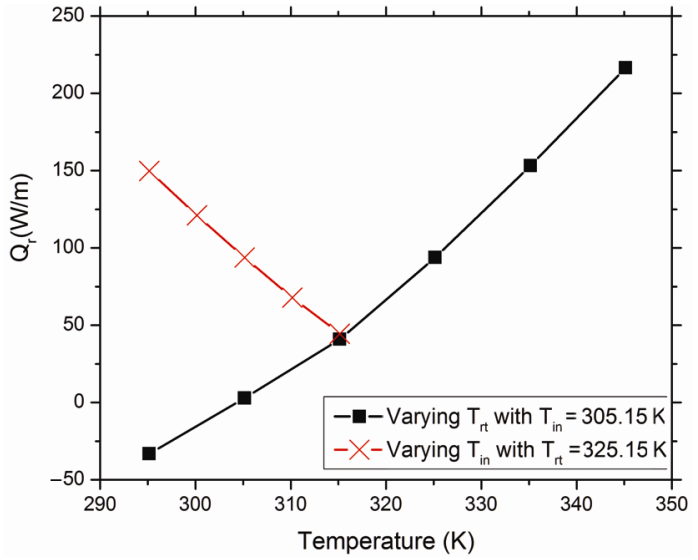

Fig. 13. Predicted heat gain from roof as a function of the ambient and roof-top temperatures for the sealed and vented attics

The cooling load of the vented attic increases monotonically with the ambient temperature. As the ambient temperature increases from $295.15 \mathrm{~K}$ to $315.15 \mathrm{~K}$ while the roof-top temperature is fixed at $325.15 \mathrm{~K}$, the attic cooling load is predicted to increase by $269 \%$.

The ventilating mass flow rate through the vented attic increases monotonically with the roof-top temperature and decrease monotonically with the ambient temperature. This indicated solar irradiance actually provides energy for the self-cooling natural ventilation by significantly increasing upward airflow rate. the For a given ambient temperature of $305.15 \mathrm{~K}$, the upward air flow increases by $41 \%, 70 \%$, and $92 \%$, respectively, as the roof-top temperature increases from $315.15 \mathrm{~K}$ to $325.15 \mathrm{~K}, 335.15 \mathrm{~K}$, and $345.15 \mathrm{~K}$. For a fixed roof-top temperature of $325.15 \mathrm{~K}$, the ventilating mass flow rate decreases by $9 \%, 19 \%, 31 \%$, and $48 \%$, respectively, as the ambient temperature increases from $295.15 \mathrm{~K}$ to $300.15 \mathrm{~K}, 305.15 \mathrm{~K}, 310.15 \mathrm{~K}$, and $315.15 \mathrm{~K}$.

\section{Acknowledgments}

This study was partially supported by the Faculty Seed Grants from the University of Nebraska-Lincoln (20092010). 


\section{References}

Al-Khameis, M.; Mahmoud, M.; Ben-Nakhi, A.; Mahmoud, A. M.; Ben-Nakhi, A. 2011. Coupled heat transfer modes for calculation of cooling load through hollow concrete building walls, Journal of Building Performance Simulation 4(2): 125-140. http://dx.doi.org/10.1080/19401493.2010.507821

ANSYS, Inc. 2011. ANSYS FLUENT 13.0. Canonsburg, PA, USA.

Asan, H.; Namli, L. 2000. Laminar natural convection in a pitched roof of triangular cross-section: summer day boundary conditions, Energy and Buildings 33(1): 69-73. http://dx.doi.org/10.1016/S0378-7788(00)00066-9

Blay, D.; Mergui, S.; Niculae, C. 1992. Confined turbulence mixed convection in the presence of a horizontal buoyant wall jet, ASME HTD 213: 65-72.

Blocken, B.; Stathopoulos, T.; Carmeliet, J.; Hensen, J. L. M. 2011. Application of computational fluid dynamics in building performance simulation for the outdoor environment: an overview, Journal of Building Performance Simulation 4(2): 157-184. http://dx.doi.org/10.1080/19401493.2010.513740

Chen, Q. 2009. Ventilation performance prediction for buildings: a method overview and recent applications, Building and Environment 44(4): 848-858. http://dx.doi.org/10.1016/j.buildenv.2008.05.025

Chen, Q.; Srebric, J. 2002. A procedure for verification, validation, and reporting of indoor environment CFD analyses, HVAC\&R Research 8(2): 201-216.

Chow, C. L. 2008. Numerical studies on smoke spread in the cavity of a double-skin façade, Journal of Civil Engineering and Management 17(3): 371-392.

http://dx.doi.org/10.3846/13923730.2011.595075

Cropper, P. C.; Yang, T.; Cook, M.; Fiala, D.; Yousaf, R. 2010. Coupling a model of human thermoregulation with computational fluid dynamics for predicting humanenvironment interaction, Journal of Building Performance Simulation 4(3): 233-243.

http://dx.doi.org/10.1080/19401491003615669

Džiugaitė-Tumėnienė, R.; Jankauskas, V.; Motuzienė, V. 2012. Energy balance of a low energy house, Journal of Civil Engineering and Management 18(3): 369-377. http://dx.doi.org/10.3846/13923730.2012.691107

D\&R International. 2012. 2011 buildings energy data book. U.S. Department of Energy.

Flack, R. D. 1980. The experiment al measurement of natural convection heat transfer in triangular enclosures heated or cooled from below, ASME Journal of Heat Transfer 102(4): 770-772. http://dx.doi.org/10.1115/1.3244389

Flack, R. D.; Witt, C. L. 1979. Velocity measurements in two natural convection air flows using a laser velocimeter, ASME Journal of Heat Transfer 101(2): 256-260. http://dx.doi.org/10.1115/1.3450956

Goldsworthy, M. 2012. Dynamic coupling of the transient system simulation and fire dynamics simulation programs, Journal of Building Performance Simulation 5(2): 105114. http://dx.doi.org/10.1080/19401493.2010.546430

Henkes, R. A. W. M.; Hoogendoorn, C. J. 1994. Scaling of the turbulent natural convection flow in a heated square cavity, ASME Journal of Heat Transfer 116(2): 400-408. http://dx.doi.org/10.1115/1.2911412

Henkes, R. A. W. M.; Van der Vlugt, F. F.; Hoogendoorn, C. J. 1991. Natural-convection flow in a square cavity calculated with low-Reynolds-number turbulence models, Inter- national Journal of Heat and Mass Transfer 34(2): 377388. http://dx.doi.org/10.1016/0017-9310(91)90258-G

Holtzman, G. A.; Hill, R. W.; Ball, K. S. 2000. Laminar natural convection in isosceles triangular enclosures heated from below and symmetrically cooled from above, ASME Journal of Heat Transfer 122(3): 485-491. http://dx.doi.org/10.1115/1.1288707

Horikiri, K.; Yao, Y.; Yao, J. 2011. Numerical simulation of convective airflow in an empty room, International Journal of Energy and Environment 4(5): 574-581.

Hsieh, K. J.; Lien, F. S. 2004. Numerical modeling of buoyancy-driven turbulent flows in enclosures, International Journal of Heat and Fluid Flow 25(4): 659-670. http://dx.doi.org/10.1016/j.ijheatfluidflow.2003.11.023

Hutchings, J. I. 1998. National codes handbook. McGraw Hill. $545 \mathrm{p}$.

Jurelionis, A.; Isevičius, E. 2008. CFD predictions of indoor air movement induced by cold window surfaces, Journal of Civil Engineering and Management 14(1): 29-38. http://dx.doi.org/10.3846/1392-3730.2008.14.29-38

Kamiyo, O. M.; Angeli, D.; Barozzi, G. S.; Collins, M. W.; Olunloyo, V. O. S.; Talabi, S. O. 2010. A comprehensive review of natural convection in triangular enclosures, ASME Applied Mechanics Reviews 63(060801): 1-13.

Kent, E. F. 2009. Numerical analysis of laminar natural convection in isosceles triangular enclosures, Proceedings of the Institution of Mechanical Engineers, Part C: Journal of Mechanical Engineering Science 223(5): 1157-1169. http://dx.doi.org/10.1243/09544062JMES1 122

Kuznik, F.; Rusaouën, G.; Brau, J. 2007. Experimental and numerical study of a full scale ventilated enclosure: comparison of four two equations closure turbulence models, Building and Environment 42(3): 1043-1053. http://dx.doi.org/10.1016/j.buildenv.2005.11.024

Laouadi, A. 2009. Thermal performance modelling of complex fenestration systems, Journal of Building Performance Simulation 2(3): 189-207. http://dx.doi.org/10.1080/19401490903046785

Lei, C.; Armfield, S. W.; Patterson, J. C. 2008. Unsteady natural convection in a water-filled isosceles triangular enclosure heated from below, International Journal of Heat and Mass Transfer 51(11-12): 2637-2650.

http://dx.doi.org/10.1016/j.ijheatmasstransfer.2007.09.036

Medina, M. A.; O’Neal, D. L.; Turner, W. D. 1998a. A transient heat and mass transfer model of residential attics used to simulate radiant barrier retrofits, Part I: development, ASME Journal of Solar Energy Engineering 120(1): 3238. http://dx.doi.org/10.1115/1.2888044

Medina, M. A.; O’Neal, D. L.; Turner, W. D. 1998b. A transient heat and mass transfer model of residential attics used to simulate radiant barrier retrofits, Part II: validation and simulations, ASME Journal of Solar Energy Engineering 120(1): 39-44. http://dx.doi.org/10.1115/1.2888044

Moujaes, S. F.; Alsaiegh, N. T. 2000. Numerical heat transfer attic model using a radiant barrier system, Journal of Energy Engineering 126(1): 32-51. http://dx.doi.org/10.1061/(ASCE)07339402(2000)126:1(32)

Ozoe, H.; Mouri, A.; Ohmuro, M.; Churchill, S. W.; Lior, N. 1985. Numerical calculations of laminar and turbulent natural convection in water in rectangular channels heated and cooled isothermally on the opposing vertical walls, International Journal of Heat and Mass Transfer 28(1): 125-138. http://dx.doi.org/10.1016/0017-9310(85)90014-6 
Parasonis, J.; Keizikas, A.; Endriukaitytè, A.; Kalibatienė, D. 2012. Architectural solutions to increase the energy efficiency of buildings, Journal of Civil Engineering and Management 18(1): 71-80. http://dx.doi.org/10.3846/13923730.2011.652983

Poulikakos, D.; Bejan, A. 1983. Natural convection experiments in a triangular enclosure, ASME Journal of Heat Transfer 105(3): 652-655. http://dx.doi.org/10.1115/1.3245635

Ridouane, E. H.; Campo, A.; Hasnaoui, H. 2006. Turbulent natural convection in an air-filled isosceles triangular enclosure, International Journal of Heat and Fluid Flow 27(3): 476-489. http://dx.doi.org/10.1016/j.ijheatfluidflow.2005.10.013

Ridouane, E. H.; Campo, A.; McGarry, M. 2005. Numerical computation of buoyant airflows confined to attic spaces under opposing hot and cold wall conditions, International Journal of Thermal Sciences 44(10): 944-952. http://dx.doi.org/10.1016/j.ijthermalsci.2005.03.008

Rose, W. B.; TenWolde, A. 2002. Venting of attics and cathedral ceilings, ASHRAE Journal 44: 26-33.

Rudd, A. F.; Lstiburek, J. W. 1998. Vented and sealed attics in hot climates, ASHRAE Transactions 104: 1199-1210.

Saber, H. H.; Maref, W.; Elmahdy, H.; Swinton, M. C.; Glazer, R. 2012. 3D heat and air transport model for predicting the thermal resistances of insulated wall assemblies, Journal of Building Performance Simulation 5(2): 75-91. http://dx.doi.org/10.1080/19401493.2010.532568

Saha, S. C. 2011. Unsteady natural convection in a triangular enclosure under isothermal heating, Energy and Buildings 43(2-3): 695-703. http://dx.doi.org/10.1016/j.enbuild.2010.11.014

Saha, S. C.; Khan, M. M. K. 2011. A review of natural convection and heat transfer in attic-shaped space, Energy and Buildings 43(10): 2564-2571. http://dx.doi.org/10.1016/j.enbuild.2011.06.020

Saha, S. C.; Patterson, J. C.; Lei, C. 2010. Natural convection and heat transfer in attics subject to periodic thermal forcing, International Journal of Thermal Sciences 49(10): 1899-1910.

http://dx.doi.org/10.1016/j.ijthermalsci.2010.05.010
Sartipi, A.; Laouadi, A.; Naylor, D.; Dhib, R. 2010. Convective heat transfer in domed skylight cavities, Journal of Building Performance Simulation 3(4): 269-287. http://dx.doi.org/10.1080/19401491003653611

Talabi, S. O.; Olunloyo, V. O. S.; Kamiyo, O. M.; Collins, M. W.; Karayiannis, T. G. 2006. Flow field and Reynolds stress distribution in low turbulence natural convection in a triangular cavity, in Hanjalic, K.; Nagano, Y.; Jakirlic, S. (Eds.). Proceedings of Fifth International Symposium on Turbulence, Heat and Mass Transfer, 26-29 September 2006, Dubrovnik, Croatia, 511-514. http://dx.doi.org/10.1615/ICHMT.2006.TurbulHeatMassT ransf. 1060

Walters, D. K.; Cokljat, D. 2008. A three-equation eddyviscosity model for Reynolds-averaged Navier-Stokes simulations of transitional flow, Journal of Fluid Engineering 130(121401): 12-14.

Wang, S.; Shen, Z.; Gu, L. 2012. Numerical simulation of buoyancy-driven turbulent ventilation in attic space under winter conditions, Energy and Buildings 47: 360-368. http://dx.doi.org/10.1016/j.enbuild.2011.12.012

Zhang, W.; Chen, Q. 2000. Large eddy simulation of natural and mixed convection airflow indoors with two simple filtered dynamic subgrid scale models, Numerical Heat Transfer A 37(5): 447-463. http://dx.doi.org/10.1080/104077800274154

Zhang, Z.; Zhang, W.; Zhai, Z.; Chen, Q. 2007. Evaluation of various turbulence models in predicting airflow and turbulence in enclosed environments by CFD: part 2 - comparison with experimental data from literature, $H V A C \& R$ Research 13: 871-886.

Zuo, W.; Chen, Q. 2009. Real time of faster-than-real-time simulation of airflow in buildings, Indoor Air 19(1): 3344. http://dx.doi.org/10.1111/j.1600-0668.2008.00559.x

Zhigang SHEN. Assistant Professor of Construction Management in the College of Engineering at the University of Nebraska-Lincoln. In his research areas he received multiple research grants sponsored by US federal agencies, including NSF, EPA and DOE. His main research interests are energy efficient building design and construction, virtual built environment, and virtual learning and training in design and construction.

Shimin WANG. Post-doctoral Research Associate of Construction Management in the College of Engineering at the University of Nebraska-Lincoln. His current research focus is CFD applications in energy efficient building design and construction. 